\title{
So Long Solange? The PSPP Judgment of the German Constitutional Court and the Conflict between the German and the European 'Popular Spirit'
}

\author{
Peter HILPOLD \\ University of Innsbruck
}

\begin{abstract}
The judgment by the German Constitutional Court ('BVerfG') of 5 May 2020 has caused a stir all over Europe. The relationship between the BVerfG and the European Court of Justice ('ECJ') has never been an easy one, especially after the Solange judgment of 1974. The Solange jurisprudence has, however, not only been synonymous with conflict and rivalry but also for dialogue and, eventually, mutual respect. With the PSPP judgment, this dialogue seemed to have found an end, while by the order of 29 April 2021 the BVerfG appears to have returned to a more conciliatory tone. Nonetheless, the disruption between Karlsruhe and Luxembourg persists.

In this article, the PSPP judgment will be examined in detail, presenting it as the last step of long, contorted jurisprudence. It will be shown that the rupture that occurred in May 2020 was technically unnecessary and rather the result of deeprooted cultural conflict with a clear economic background. The legal reasoning on both sides - that of the BVerfG and that of the PSPP judgment's most outspoken critics-is problematic at best. While for the time being the BVerfG seems to have learnt the lesson from the conflict provoked by its own judgment, the underlying, substantive conflict is still unresolved.

It will be shown that this conflict can only be solved on a political level. Thereby, cultural pre-concepts will have to be overcome. Uncompromising reliance on a national 'popular spirit' (Volksgeist) will not offer a way out but neither will, for the time being, exclusive reference to a European Volksgeist ignoring Member State realities. The 'weighing and balancing' the BVerfG has missed in the previous Weiss ECJ preliminary ruling (again on the PSPP programme) will have to take place on a far broader scale.
\end{abstract}




\section{INTRODUCTION}

The judgment of the German Constitutional Court (Bundesverfassungsgericht, or BVerfG) of 5 May 2020, ${ }^{1}$ has caused stir all over Europe. ${ }^{2}$ In this judgment, first of all, the primacy of EU law over the law of the Members States has been put in jeopardy. ${ }^{3}$ But the problems with this pronunciation reach far beyond this issue. What is perhaps even more troubling is the fact that this sentence not only signals a power struggle between the centre and the periphery in general ${ }^{4}$ but it is rather one specific Constitutional Court, the one of the most powerful State within the EU, that tries to dictate its visions of the correct interpretation of EU law, its perception on how the relationship between the European Court of Justice ('ECJ') and all legal systems of the EU's Member States should be structured, to the EU institutions and, subsequently, also to all the other Member States. ${ }^{5}$

By its order of 29 April $2021{ }^{6}$ the BVerfG appears to have retreated from the stance taken a year before, but the underlying problem is nonetheless unresolved. In fact, hand in hand with the judgment of 5 May goes a new reading of EU law, an attempt to prevail in a struggle over the method and vision in EU law. This struggle has become even more exacerbated as a consequence of the United

\footnotetext{
1 BVferG, Judgment of 5 May 2020, 2 BvR 859/15, 1651/15, 2006/15, 980/16.

2 For an overview on first reactions for and against the PSPP judgment, see Stephan Wernicke, 'Ist
} Europa sterblich? Eine rechtstheologische Rekonstruktion der Debatte um das EZB-Urteil des Bundesverfassungsgerichts', Europäische Zeitschrift für Wirtschaftsrecht (EuZW) 2020, p 543.

3 As is well-known, this is a concept developed by the European Court of Justice in Costa $v$ Enel in 1964, Judgment of 15 July 1964, ECLI:EU:C:1964:66. In 2004 it was tried to transform this principle into a positive norm by inserting it into Article I- 6 of the Treaty establishing a Constitution for Europe a document which, however, never came into force. In a somewhat weakened form reference to primacy is now to be found in Declaration No 17 of the Lisbon Treaty. When, on 7 October 2021, the Polish Constitutional Tribunal challenged the supremacy of EU law in respect to Polish constitutional law, this landmark judgment of potentially disruptive effects for European integration, was portrayed by many also as an outflow of the PSPP Judgment of 5 May 2020 (Case K 3/21).

${ }^{4}$ Such struggles have happened already in the past and the open challenge of the pre-eminence of EU law is not without precedent; see the Landtová case decided by the Czech Constitutional Court In 2012 (Judgment of 31 January 2012, Pl. ÚS 5/12) and challenging ECJ, 22 June 2011, Landtová v Česká správa socialního zabezpečení, C-399/09, ECLI:EU:C:2011:415 and the Ajos case decided by the Danish Constitutional Court in 2016 (Judgment of 6 December 2016, Case 15/2014, Dansk Industri (DI) acting for Ajos A/S $v$ The estate left by Karsten Eigil Rasmussen) and referring to ECJ, 19 April 2016, C-441/14, ECLI:EU:C:2016:278: see U Sadl and S Mair, 'Mutual Disempowerment' (2017) 13 European Constitutional Law Review 347. However, these cases concern issues of relatively secondary importance. Compared to the PSPP case, however, these matters regard rather marginal issues and they are not suited to undermine the dialogue between the ECJ and the national Constitutional Courts in such a far-reaching way.

5 See, with unmatched irony the Editorial Comment in (2020) 57 CMLR pp 965-77: 'This is [...] a strongly-worded decision delivered with all the confidence of members of an institution that would very comfortably accept the compliment of being primus inter pares among constitutional courts in Europe and, come to think of it, well beyond'.

62 BvR 1651/15 and 2 BvR 2006/15. 
Kingdom's departure from the EU and it can become virulent again at any time in the future. The letter of formal notice sent by the European Commission to Germany on 9 June 2021 for violation of fundamental principles of EU law, in particular the principles of autonomy, primacy, effectiveness and uniform application of Union law, as well as the respect of the jurisdiction of the European Court under Article 267 of the Treaty on the Functioning of the European Union ('TFEU') ${ }^{7}$ demonstrates that for the European Commission the BVerfG has trespassed a red line. More fundamental clarifications are now needed.

In this article, particular attention will be given to these methodological issues. At the same time, however, one cannot ignore that this controversy goes far beyond a mere discord on abstract theory and method: this struggle for 'Deutungshoheit', for interpretational sovereignty, hides the attempt, so it is suggested here, to steer also the material operation of EU law and decision procedures with far-reaching consequences on economic and financial levels. As will be seen, in the complex interrelationship between the various economic, political and societal forces and facts within the European Union, it is next to impossible to determine definite causalities or to offer a picture with mathematical precision about how the various stakeholders contribute to wealth creation. Neither is it possible to provide an objective assessment on how re-distribution should be structured in view of the aim to provide for more solidarity. All these aims and values are, to a large extent, politically determined and the result of the related assessment procedures are generally path dependent. The country or the institution that sets out the course for these procedures will be able to influence, to a considerable measure, the outcome of decisions on material resource distribution, which may seem, on their face, neutral and objective. Such a preponderance of power by one Member States was not workable within a Community of Six and it is even less so in a Union of 27.

In the following, it will be shown that the PSPP judgment is only one-even though rather drastic - step in a process often qualified by the Solange term. This discussion seems to be, at first glance, rather theoretic and legalistic and to a considerable extent this is also the case. At the same time, however, this dispute only covers a more substantive rift within the European Union that has become more pronounced by the financial crisis starting in 2007 and afterwards by the coronavirus crisis. It will be shown that the legal arguments trying to cover the more material controversy are in many ways flawed. The PSPP judgment gives testimony to this in a very pronounced way. At the same time, however, it will also be outlined that the underlying conflict is real and that it can only be overcome by political means.

7 See European Commission, June infringements package: key decisions, https://ec.europa.eu/ commission/presscorner/detail/en/inf_21_2743 (23 June 2021). 


\section{A FEW WORDS ABOUT THE SOLANGE JURISPRUDENCE - 'LA QUERELLE ALLEMANDE ${ }^{, 8}$}

\section{A. The Roots of the Solange Jurisprudence}

What originally had been qualified as a mere 'querelle allemande', 9 in the following decades accompanied and, in many ways, also steered the whole European integration process. At first sight, it might seem awkward that this conflict broke out in Germany because this country has been, in the first years of the European integration process, among the staunchest supporters of this process and the German Constitutional Court fully supported this political attitude. The understanding of the German Federal Republic as an antithesis to the Nazi terror regime, an idea so vividly expressed by the BVerfG in the 'Wunsiedel Order' of 4 November 2009, ${ }^{10}$ was, at least implicitly, an essential element of the Constitutional Court's selfperception, and a maximum of openness ${ }^{11}$ towards European integration should be an important means to implement this ambition. ${ }^{12}$ This pro-European attitude was, however, not a consistent one. It was rather subject to continuous mood changes depending on external developments, such as economic crises, as well as on the influence of individual opinion leaders. It may be no coincidence that the spreading of Euroscepticism in Germany towards the beginning of the 1970s went in parallel with the end of the 'economic miracle' ('Wirtschaftswunder') that had transformed a Germany in ruins after World War II into a prosperous, economically leading country.

Among German Public Lawyers, Professor Hans-Heinrich Rupp (1926-2000) became the main opponent of European Community law's supremacy pointing at a 'structural incoherence' between European Community ('EC') law and German

8 See in this regard also P Hilpold, 'Solange I, BVerfGE 37, 291, 29 May 1974; Solange II, BVerfGE 73, 339, 22 October 1986; Solange III, BVerfGE 89, 15512 October 1993; and Solange IV, BVerfGE 102, 147, 7 June 2000', in C Ryngaert, et al (eds), Judicial Decisions on the Law of International Organization (Oxford University Press, 2016).

9 See P Ipsen, Europäisches Gemeinschaftsrecht (Mohr, 1972), pp $716 \mathrm{ff}$.

10 BVerfG, Order of the First Senate of 4 November 2009, 1 BvR 2150/08, paras 1-87.

11 The 'open constitutional state' ('der offene Verfassungsstaat') became a central leitmotiv for the German constitutional thinking. See K Vogel, Die Verfassungsentscheidung des Grundgesetzes für eine internationale Zusammenarbeit (Mohr, 1964); S Hobe, Der Offene Verfassungsstaat zwischen Souveränität und Interdependenz. (Duncker \& Humblot, 1998); T Giegerich (ed), Der 'offene Verfassungsstaat' des Grundgesetzes nach 60 Jahren: Anspruch und Wirklichkeit einer großen Errungenschaft (Duncker \& Humblot, 2010). As it has been recently portrayed in literature, the 'European integration option' has eventually been without alternative-after all the disastrous trials and tribulation of the past. See HA Winkler, Der lange Weg nach Westen, Vols. 1 \& 2 ( Beck, 2014).

12 See also C Tomuschat, 'Staatsrechtliche Entscheidung für die internationale Offenheit' in J Isensee and P Kirchhof (eds), Handbuch des Staatsrechts der Bundesrepublik Deutschland, Band 11: Internationale Bezüge, (Müller, 2013), who refers in this context to the preamble, to Articles 24-26 of the German Constitution (Grundgesetz ('GG')) and to the 'Europe clause' in Article 23, para 1 GG which has been in force since 1992. These provisions required Germany 'to operate not in autocratic isolation but in cooperation with the other European peoples'. Ibid, $\S 3$. 
national constitutional law. ${ }^{13}$ The Solange I judgment of $1974{ }^{14}$ gave full expression to this new, critical vision about the relationship between EU law and German national (constitutional) law.

The immediate bone of contention was fundamental rights protection. There can be no doubt that the German 'Grundgesetz' provides for a high level of protection. German lawyers regularly take much pride ${ }^{15}$ in this and a rather 'introverted' perspective taken by some German constitutional lawyers in these circumstances is exalted. ${ }^{16}$ In a certain way, fundamental rights protection became the most distinguishing feature of German constitutional law, a quality that distinguished this national legal order from EC law in a decisive way, being suited also to provide moral superiority to this constitution. ${ }^{17}$

In the following, both parties seemed to recognise the explosiveness of this situation. In the Solange I judgment, the BVerfG put into jeopardy Van Gend en $\operatorname{Loos}^{18}$ and the very concept of primacy of EC law, while also the EC and, respectively, the ECJ, claiming the role of this order's main legal interpreter, had to admit an open flank when it had next to no response to the criticism that the EC lacked meaningful human rights protection provisions. This deficit had become all the more acute in view of its expanding fields of competence and activity.

13 See B Davies, Resisting the European Court of Justice (Cambridge University Press, 2012), pp $180 \mathrm{ff}$. It may be interesting to read a piece that Professor Rupp wrote more than thirty years later, in 2003 (H-H Rupp, 'Anmerkungen zu einer Europäischen Verfassung' (2003) 58 Juristenzeitung 18), about the proposed (and ultimately failed European Constitution). There he had to accept that the primacy of EC law had to be recognised as a matter of fact, but he continues to strongly criticise this development as dogmatically unsustainable and as infringing upon core values of the German Constitution. For him, national constitutions had 'broken down, piece by piece' and he proposed to remediate by abolishing both the flexibility clause in Article 308 European Community Treaty ('ECT') (now Article 352 TFEU) and the rules on law harmonisation in Article 95 ECT (now Article 114 TFEU).

14 BVerfG, 2nd Senat, 5 May 2020, 2 BvR 859/15.

15 For the exuberant language used in this regard see, for example, R Scholz, 'Grundrechtsschutz in der Europäischen Union und in der Bundesrepublik Deutschland über das Bundesverfassungsgericht, den Europäischen Gerichtshof und den Europäischen Gerichtshof für Menschenrechte ' (2017) 35/2 Ritsumeikan Law Review 15, p 15: 'Die Bundesrepublik Deutschland verfügt mit ihrem Grundgesetz über eine Grundrechtsordnung, die in ihrer Stringenz wie Effektivität international vielfach als wahrhaftiges Vorbild empfunden wird'.

16 On this attitude that began changing to more openness towards a comparative analysis only at the beginnings of the 1990s see P Häberle, 'Book review of Christian Stark (ed), Grundgesetz und deutsche Verfassungsrechtsprechung im Spiegel ausländischer Verfassungsentwicklung' (1992) 117 Archiv des öffentlichen Rechts 283, p 284.

17 The pathos of this judgment's wording gave further impetus to this sensation: 'The part of the Basic Law dealing with fundamental rights is an alienable, essential feature of the valid Basic Law of the Federal Republic of Germany and one which forms part of the constitutional structure of the Basic Law'. English translation at The University of Texas at Austin, School of Law, Institute for Transnational Law, Foreign Law Translation, http://www.utexas.edu/law/academics/centers/ transnational/work_new/german/case.php?id=588.

18 Case 26-62, Van Gend en Loos, ECLI:EU:C:1963:1, Judgment of 5 February 1963. 
The ECJ managed to overcome the contested deficit in human rights protection by an astute manoeuvre, namely by extracting fundamental rights from the national constitutional orders and transplanting them as 'general principles of EU law' into the EU legal order. This approach had already been started earlier, ${ }^{19}$ but Solange I had given the decisive impetus to intensify further this process. ${ }^{20}$

When, more than a decade later, the BVerfG was again confronted with this issue, in the Solange II case, ${ }^{21}$ this Court could refer to the jurisprudential developments that had taken place in the preceding years and acknowledge that fundamental rights protection provided by the EC was 'substantially similar to the protection of fundamental rights required unconditionally by the Basic Law'. As a consequence,

and in so far as they generally safeguard the essential content of fundamental rights, the Federal Constitutional Court will no longer exercise its jurisdiction to decide on the applicability of secondary Community legislation cited as the legal basis for any acts of German courts or authorities within the sovereign jurisdiction of the Federal Republic of Germany, and it will no longer review such legislation by the standard of the fundamental rights contained in the Basic Law; references to the Court under Article 100 (1) for that purpose are therefore inadmissible'. ${ }^{22}$

At first sight, this judgment set an end to a long diatribe. It could even be argued that this judgment implied the acceptance of the ECJ's jurisprudence pre-eminence by the BVerfG. The conditions set by the BVerfG to the acceptance of this prerogative could be interpreted as merely formal and abstract with no real-life implications as it was unrealistic that the EC would again fall back behind the standards achieved.

The subsequent developments, however, proved this impression wrong. The struggle for the last word on issues of basic constitutional relevance was reignited a few years later. Thereby it became clear that the controversy standing at the basis of the Solange jurisprudence had not been a mere attempt to safeguard the high fundamental rights protection standard of the Basic Law but the perception of legal if not moral pre-eminence within the European legal order revealed to be of a much broader scale. The Solange jurisprudence had demonstrated that such a challenge was possible, that it could be conducted in a way no other European constitutional Court could dare to do, and that it had led to an outcome that the BVerfG could sell as a success for Germany. The German Constitutional Court had been able to impress its own understanding of the rule of law on the whole EC. With the job done in the field of fundamental rights protection, attention shifted to other areas, in part to protect characteristics of the German constitutional order against EC/EU harmonisation tendencies, in part to impose typical German values on the whole Community/Union. Eventually, in the PSPP dispute, it was basic principles of the economic philosophy

\footnotetext{
19 See the famous Stauder case: Case 297-69, Stauder, ECLI:EU:C:1969:57, Judgment of 12 November 1969.

20 See A Haratsch, C Koenig, and M Pechstein, Europarecht (Mohr, 2020), p 323.

21 Solange II, BVerfGE 73, 339 (22 October 1986).

22 Ibid, II, 1(f).
} 
prevailing in Germany that should be transferred to the Union as a whole, thereby also imposing a specific model of solidarity and of economic and fiscal policy useful specifically for this country.

\section{B. The Maastricht Judgment of 12 October 1993}

In this discussion, the Maastricht judgment of 1993 was a turning point. ${ }^{23}$ This treaty implied the most far-reaching step ahead in the European integration process since its inception - and for some it was too far-reaching. Thus, before the BVerfG a series of individual complaints was lodged against the German federal statute ratifying the Treaty. The complaints were dismissed but the BVerfG used the opportunity to make some obiter dicta that should rebalance the relationship between the Union and the Member States (more specifically: Germany) in a decisive manner: ${ }^{24}$

- The BVerfG reiterated its willingness, already expressed in Solange II to guarantee fundamental rights protection 'in cooperation' with the ECJ, but at the same time the German Constitutional Court asserted its intention to exercise this control also against the European Union. ${ }^{25}$ As it was appropriately said, this statement sounded more as an announcement to exercise 'final control' than as an offer for cooperation.

- Particular emphasis was laid on the consideration that no 'Kompetenz-Kompetenz' was conferred to the European Union. Therefore, an extensive interpretation of EU law by the ECJ also would lack a competence basis and therefore not be binding on Germany. ${ }^{26}$

- Community Acts going beyond the conferred powers would not be binding on Germany and could be controlled by the German Constitutional Court. ${ }^{27}$

The Maastricht judgment laid bare the inconsistencies resulting from the fact that the EC, on the one hand, had evidently international law origins and should necessarily have limited powers (principle of conferral) and, on the other hand, the EC was claiming autonomy and a sui generis status. ${ }^{28}$ The BVerfG opted for a 'return to the international law roots' that should also protect Germany's sovereignty (and that of the BVerfG) to the utmost. This attitude was further emphasised by the Union's qualification as an 'association of States' ('Staatenverbund') to be distinguished from a state proper.

23 BVerfG, 12 October 1993, Az 2 BvR 2134, 2159/92, BVerfGE 89, 155.

${ }^{24}$ See in this regard also T C Hartley, European Union Law in a Global Context: Text, Cases and Materials (Cambridge University Press, 2004), p 159.

251 Common Market Law Reports 57, para 13. See M Herdegen, Europarecht, $12^{\text {th }}$ ed (Beck, 2010), p 252.

261 Common Market Law Reports 57, para 99.

27 Ibid, para 46.

28 Starting with Van Gend en Loos. 
Dogmatically, it is not possible to easily dismiss this perspective, even though if applied to the European integration process from the very beginning it would have made this process next to impossible. What the BVerfG wanted to achieve was to retain control over the European integration process at an important juncture where this process seemed to head for a significant intensification. To achieve this end, the challenge was twofold:

- First of all, the BVerfG had to extend its control activity beyond the fundamental rights issue. EU competences had become so vast that infringements with basic elements of the German constitutional order should become possible in a broad array of fields not always and not easily attributable to the fundamental rights area. The BVerfG became now interested in the protection of national legislative competences in general, even though only fundamental breaches should justify intervention. In this context, the ultra vires doctrine was developed: the German Constitutional Court should make sure that the EU is not overstepping its competences, otherwise these acts should not display any effect on German soil.

- The next challenge was to create a legal mechanism that would allow the Court to oversee and control this relationship between EU law and national law in a continuous way, with such an instrument clearly lacking in the given constitutional order. True, there was the possibility that such an issue would come up in a proceeding among supreme federal bodies ${ }^{29}$ but the factual possibility of such proceedings are rather remote-not least because the traditional 'Europe friendliness' characterising the whole German constitutional order and political system, still constitutes a strong barrier to act in such a way for political bodies. Therefore, a new instrument had to be created — only based on case law.

It is tempting, therefore, to interpret the findings by the BVerfG as to the newly identified individual right to complaint against integration measures on the basis of Article $38 \mathrm{GG}$ in this light. ${ }^{30}$ In fact, the most distinguishing feature of the Maastricht judgment with the most far-reaching effect may exactly be found in the findings on the enlarged admissibility of individual complaints against integration measures or, more precisely, their implementation by Germany. As a legal construct, these findings seem hardly convincing and were met with harsh criticism by German constitutionalists. ${ }^{31}$ The German Constitutional Court managed, however,

\footnotetext{
${ }^{29}$ Such issues can be referred to the BVerfG by judicial review on the basis of Article 93, para 1, no 2 (abstract judicial review of norms); Article 100 para $1 \mathrm{GG}$ (concrete judicial review of norms), or in disputes between the Federation and the Länder pursuant to Article 93, para 1, no 3 GG. See M Herdegen, Europarecht, $22^{\text {nd }}$ ed (Mohr, 2020), para 32.

30 The immediate procedural basis is here to be found in Article 93, para 1, no 4a (claim by any person- 'jedermann'-whose fundamental rights or his or her rights pursuant to Articles 20, para 4, 33, 38, 101, 103, and 104 are breached).

31 See, for example, F C Mayer, in several writings. See, among others, 'Auf dem Weg zum Richterfaustrecht?: Zum PSPP-Urteil des BVerfG' (VerfBlog, 7 May 2020), https://verfassungsblog. de/auf-dem-weg-zum-richterfaustrecht; H Dreier in H Dreier (ed), Grundgesetz, Kommentar, $3^{\text {rd }}$ ed
} 
to develop an individual complaint basis not explicitly foreseen in the Constitution and conceived in a way so to become strictly shielded against any attack by the Parliament. It also formed the basis for the PSPP complaint.

To this end, the Constitutional Court referred to the right to vote enshrined in Article $38 \mathrm{GG}$ and interpreted this right not only in a procedural way but also in substantive one:

Article 38 not only contains a safeguard to ensure that the citizen is accorded the right to elect the German Bundestag and that in the election the constitutional principles of electoral law will be upheld, the safeguard also extends to the fundamental democratic content of that right: what is guaranteed to German entitled to vote is the individually assertable right to participate in the election of the Bundestag and thereby to co-operate in the legitimation of state power by the people at federal level and to have an influence over its exercise. ${ }^{2}$

The individual is promoted to be the guardian as to whether the European integration process corresponds to the German constitution:

The complainant's right arising from Article 38 of the Constitution can therefore be infringed if the exercise of the powers within the competence of the Bundestag is transferred to an institution of the European Union or European Communities formed by the member-States' governments to such an extent that the minimum requirements, which under Article 20(1) and (2) in conjunction with Article 79(3) may not be dispensed with, for the democratic legitimation of the sovereign power exercised in respect of citizen are no longer satisfied. ${ }^{32}$

By the connection of this (newly found) material content ${ }^{33}$ of Article 38 with Article 20 (1) and (2) (constitutional principle of democracy) and Article 79 (3) (inadmissibility of constitutional changes regarding the principle of democracy- 'eternity clause' ('Ewigkeitsklausel') — and the recognition of an individual right to complaint to effectively safeguard this right, the BVerfG created a powerful instrument making sure that questions of European integration would be presented to this Court on a continuous basis. In fact, it can be taken for granted that there will always be at least a few individuals taking issue with the further integration process and willing to present a

\section{(F'note continued)}

(Mohr Siebeck, 2013), Art 20(D), para 123; M Sachs, 'Grundrechtsschutz der Staatlichkeit und der Staatsstrukturprinzipien?' in M Sachs and H Siekmann, Der grundrechsgeprägte Verfassungsstaat Festschrift für Klaus Stern zum 80. Geburtstag, (Berlin, Duncker \& Humblot, 2012), p 597; S Magiera in M Sachs (ed), Grundgesetz, $8^{\text {th }}$ ed (Beck, 2018), Art 20, para 80(s). Judge Gertrude Lübbe-Wolff qualified this jurisprudence in her Dissenting Opinion on the Order of the Second Senate of 14 January 2013 (OMT) as an 'originally bold, now established doctrine of the Court's case law'. Ibid, para 15, reprinted in Neue Zeitschrift für Verwaltungsrecht (NVwZ) (2014), p 514.

321 Common Market Law Reports 57, B(6).

33 See H Ehlers, 'Verhältnis des Unionsrechts zu dem Recht der Mitgliedstaaten' in R Schulze, et al (eds), Europarecht (Beck, 2020), p 549, para 32, referring to BVerfGE 89, 155, $171 \mathrm{ff} ; 123,267,340 \mathrm{ff}$; 123, 267, $340 \mathrm{ff} ; 129,124,167 \mathrm{ff} ; 134,366,381,396 \mathrm{ff}$. 
complaint before the BVerfG. This 'subjectivisation of objective law', as it was called, ${ }^{34}$ lasts, however, for the first step of this procedure - it regards only its setting in motion. It will then be the Constitutional Court to decide whether to retain this complaint as admissible or not and subsequently whether to accept or to dismiss it. This strategic re-interpretation of the concept of subjective rights risks imperilling fundamental rights protection as a whole. ${ }^{35}$ Reference to the 'eternity clause' in Article 79 (3) should have as a consequence that this right to complaint would become eternal in itself with the German Parliament not being allowed to abolish it even by legislative measures.

There are limits within which competences can be transferred to the European level: the people's right to democratic self-determination must not be lost by this process. On the basis of this perspective, Germany could never become part of a fully integrated European Union, of a European state. The BVerfG sees itself as the guardian of a people's right to democratic self-determination defined along national lines. European integration does not thereby become impossible but the 'essence' of national self-determination has to be preserved. What does this essence mean? The BVerfG tried to define this in the following jurisprudence-with ambivalent results.

As set out above, this whole jurisprudence, the very assumption of an individual right to complaint, was met with harsh criticism in literature. It is hardly convincible to argue that limits implanted into the GG in view of Germany's experiences with a totalitarian regime should now constitute the basis for limitations as to European integration. $^{36}$

\section{The Lisbon Decision of 30 June $2009^{37}$}

The next major attempt by the BVerfG to regain control over the European integration process can be found in the Lisbon decision of 30 June 2009. By this decision, the BVerfG enlarged the purview of its examination introducing the so-called 'identity control'. This control power goes beyond the traditional question of whether the Union respects its competences (a question well-known to any federal system) as it encompasses also the question whether competences the Union can formally exercise actually violate the 'identity' of the GG. The material reference point of this 'identity control' are the inderogable guarantees in Article 23, paragraph 1, sentence 3 in connection with Article 79 Abs. $3 \mathrm{GG}^{38}$ and-with regard to EU law-Article 4 (2) of the Treaty on European Union ('TEU').

\footnotetext{
34 See D Murswiek, 'Art. 38 als Grundlage eines Rechts auf Achtung des unabänderlichen Verfassungskerns' (2010) 65 Juristenzeitung 2010 702, p 702.

35 See U Haltern, 'Ultra-vires-Kontrolle im Dienst europäischer Demokratie' [2020] $N V w Z$ 817, p 820.
}

36 See A von Bogdandy, 'Prinzipien der Rechtsfortbildung im europäischen Rechtsraum' (2010) $N J W$ 1, p 2: 'A norm introduced to protect against a relapse into dictatorship has become a protection mechanism against a European federation' (translation by this author).

37 BVerfG, Judgment of the Second Senate of 30 June 2009, 2 BvE 2/08, paras 1-421.

38 See Herdegen, note 28 above, para 37 . Whether ultra vires measures and violations of the constitutional identity are really easily (or even at all) discernible is open to debate. It can be argued that the 
In substance, the BVerfG becomes thereby the ultimate umpire in relation to political decisions regarding the European integration process. Even if the judgment about the identity of Germany's constitutional order may concern only core characteristics (the 'inviolable core content'), it will always be the Constitutional Court who defines this identity and violations thereof. The BVerfG claims for itself the right to steer this integration process like no other European Constitutional Court does. It suffices that a citizen expresses his discontent about the ongoing integration process in a formally correct complaint before the Constitutional Court and the BVerfG is free to set in motion the whole legal control process and even to sever the relevant legal links with the European Union if the free development of the German people in its main cultural traits is endangered. No other Constitutional Court of the Union has ever claimed such prerogatives. No government, not even the German one, has ever presented reservations of such a kind in occasion of one of the various treaty reforms. It is rather the BVerfG as a 'border institution' ('Grenzorgan')—a supreme judicial institution located at the border between the judiciary and the political organs ${ }^{39}$ that identified these limits setting barriers to transfer powers and competences to the European Union.

The headnotes of the Lisbon decision clearly set out this vision - with formal bows towards 'Europe friendliness' but in substance claiming prerogatives against the EU that find no basis in positive law. Here is an excerpt:

In so far as the Member States elaborate treaty law in such a way as to allow treaty amendment without a ratification procedure, whilst preserving the application of the principle of conferral, a special responsibility is incumbent on the legislative bodies, in addition to the Federal Government, within the context of participation which in Germany has to comply internally with the requirements under Article 23.1. of the Basic Law (responsibility for integration) and which may be invoked in any proceedings before the Federal Constitutional Court.

European unification on the basis of a treaty union of sovereign states may not be achieved in such a way that not sufficient space is left to the Member States for the political formation of economic, cultural and social living conditions. This applies in particular to areas which shape the citizens' living conditions, in particular the private sphere of their own responsibility and of political and social security, protected by fundamental rights, as well as to political decisions that rely especially on cultural, historical and linguistic perceptions and which develop within public discourse in the party political and parliamentary sphere of public politics.

\section{(F'note continued)}

latter category is the larger one, comprising also the former. Ultra vires acts also violate the identity of the constitutional order, but 'identity violations' may also occur in other situations. It could, however, also be argued that any 'identity violation' ends up also in an ultra vires act and a breach of competence to the detriment of the Member State. But such a position is not substantiated by any positive constitutional law.

39 See in this sense G Holzinger, 'Verfassung und Verfassungsgerichtsbarkeit' (Föderalismus Blog, 18 April 2018), http://www.foederalismus.at/blog/verfassung-und-verfassungsgerichtsbarkeit_177. php. See also note 135 below, and accompanying text. 
What is the 'sufficient space' for a Member State 'for the political formation of economic, cultural, and social living conditions'? Does it not constitute a denial of the traditional understanding of European integration trying to carve out such areas of 'national self-determination'? And what is even more disturbing: how can it be that a Member State even takes into consideration not to respect its treaty obligations if they stand in contrast to a rather nebulous 'identity' requirement autonomously defined by its Constitutional Court? ${ }^{40}$ These questions are still unsolved and they have come prominently to the fore in the PSPP proceeding as will be set out below.

Previous to this escalation, however, attempts were made by the Constitutional Court itself to limit the damage done.

\section{Banana Market Organisation ${ }^{41}$ and Honeywell ${ }^{42}$}

Both the Maastricht and the Lisbon decisions constituted unprecedented attempts to assert the German Constitutional Court's prerogatives against the ECJ, causing disconcert all over Europe. In both cases the subsequent jurisprudence by the BVerfG attempted to calm the waves and to set a step back.

In the Banana decision, taken shortly after the rapporteur of the Maastricht decision, Paul Kirchhof, had left the Court, the BVerfG stated the following:

The submitting court is of the opinion that the Federal Constitutional Court, pursuant to the Maastricht decision, contrary to the Solange II decision, explicitly exercises its review authority again, albeit in co-operation with the Court of Justice of the European Communities. This conclusion cannot be drawn from the Maastricht decision. $^{43}$

According to the BVerfG, the complaint should have contained a detailed statement that 'the protection of fundamental rights required unconditionally by the Basic Law is not generally assured in the respective case. This requires a comparison of the protection of fundamental rights on the national and on the Community level similar to the one made by the Federal Constitutional Court in BVerfGE 73, 339 (378-381)'. 44

As shown above, in the Lisbon decision the BVerfG evidenced again a much broader will to control the European integration process. In relation to Lisbon, a great step back was taken in the Honeywell decision, which gave rise to the hope that the conflict with the ECJ could be definitely resolved in an amicable way.

\footnotetext{
40 Such an ex post reservation would neither be justified by Article 27 Vienna Convention on the Law of Treaties (VCLT) nor by Article 46 VCLT.

41 BVerfG, Order of the Second Senate of 7 June 2000, 2 BvL 1/97.

42 BVerfG, Order of the Second Senate of 6 July 2010, 2 BvR 2661/06.

43 BVerfG, 7 June 2000, 2 BvL 1/97, para 64.

44 Ibid, para 62.
} 
The BVerfG clearly ruled that ultra vires review can only be considered if a breach of competences on the part of the EU is sufficiently qualified. According to the BVerfG, such a 'sufficiently qualified violation' is given if the EU is manifestly in breach of competences and the impugned act leads to a 'structurally significant shift of competences to the detriment of the Member State'.

Single violations of Member States' competences by the EU therefore do not constitute an ultra vires breach and even a multitude of such violations do not, at least not automatically. It is rather the case that a 'structurally significant shift of competences' has to occur. Therefore, the individual breach of competences is not of relevance but rather permanent, 'constitutional' changes in the federal system of the European Union that are changing the 'identity' of the Member States in violation of their right to self-determination. Conceived this way, the Solange diatribe would be converted into a true dialogue between the Union and its Member States, whereby the prospect of an outright rupture would become very remote-only fundamental violations of the constitutional consensus lying at the basis of the European integration process would generate such a conflict, and in this case rightly so.

The year 2010 seemed, therefore, to have brought peace and stability in the relations between the Union and its Member States. The main problem with this situation was, however, that in the Solange dispute it has always been the BVerfG who has dictated the conditions for peace and conflict, who blew hot and cold. In 2010, exactly when a permanent truth seemed to be in sight, the overall economic conditions in Europa were set to change profoundly and new measures of solidarity seemed to be necessary if the Economic and Monetary Union ('EMU') should be enabled to survive. In Germany, this led to controversial debates and opposition to a 'solidarity union' or a 'debt union' grew continuously. On this basis, requests for economic and cultural self-determination within the European Union found an ideal breeding ground.

At first, the BVerfG showed restraint, as it felt to have no power to judge measures adopted by the European Union but this approach was later abandoned with the Solange I judgment where the BVerfG asserted its power to examine Community Acts as to their conformity to (German) fundamental rights standards. Solange II made the actual case for such a control less probable but nevertheless the possibility of such a control was upheld. As to this point no substantial change was brought about by the following jurisprudence (in particular Maastricht, Banana Market, Lisbon, and Honeywell). The BVerfG returned to a more deferential approach towards EU law (at least formally) only in the EFS ('Greek bailout') judgment of $2011^{45}$ and, more pronouncedly (though grudgingly and with many caveats), in the $O M T$ judgment. ${ }^{46}$ The BVerfG declared itself competent only for the assessment of national acts. At first sight, this seems dogmatically correct. In practice, however, not only the dividing lines between Union law and national law become blurred and

45 BVerfGE 129, 124, EFS, of 7 September 2011.

46 BVerfGE 134, 366, OMT, of 14 January 2014. 
what 'national implementation' means is open to much controversy but the BVerfG does not even in principle fully stick to this position.

As to the first point, Judge Gertrude Lübbe-Wolff has acutely remarked that it can hardly fall into the competence of the BVerfG to judge about a mere omission of certain governmental behaviour on the Union level, first of all because of the political nature of such acts and the legal indeterminacy of the situation the judge would have to confront, a situation even more accentuated if transnational law is at issue. ${ }^{47}$

As to the inconsequentiality of the BVerfG, it has to be remembered that the 'identity control' also concerns measures that formally fall into the competence by the EU but should not have been transferred into the EU's competence because thereby core constitutional characteristics (of the German legal order) are violated. In such a situation, the BVerfG's jurisdiction concerns squarely EU acts. ${ }^{48}$

\section{E. Heading for Escalation: The OMT Quarrel between BVerfG and ECJ}

The Outright Monetary Transactions program ('OMT') dates back to the year 2012 when the European Central Bank ('ECB') announced its preparedness to operate on the secondary sovereign bond markets with the aim of safeguarding an appropriate monetary policy transmission and the singleness of the monetary policy. ${ }^{49}$ OMTs shall be part of European Financial Stability Facility/European Stability Mechanism macroeconomic adjustment programmes or precautionary programmes and be based on strict and effective conditionality. ${ }^{50}$ Already, the announcement of this possible future financing activities had considerable calming effects on the Eurozone finance markets, ${ }^{51}$ which were previously in rough waters. These announcements, which were actually never implemented on the practical level, caused fears, especially in Germany, as to a possible circumvention of Article 123 TFEU (prohibition of monetary financing of Member States), the creation of a 'debt Union' and the intrusion by the ECB into the Member States' economic policy competence. Following a complaint against Germany's participation in these measures, the BVerfG, on 14 January 2014, asked the ECJ for a preliminary ruling, the first ever in its history. As it was said, this 'request' resembled rather a 'dictate' where the BVerfG seemed to pretend that the ECJ had provided confirmation of its

47 See the Dissenting Opinion by Gertrude Lübbe-Wolff on the Order of the Second Senate of 14 January 2014, OMT, para 28, NVwZ (2014), p 514.

48 See U Häde, 'Europäischer Gerichtshof und Bundesverfassungsgericht im Spannungsfeld zwischen Selbstbehauptung und Kooperation: Die Judikatur zu den Anleihenkaufprogrammen der EZB' in M Ludwigs and S Schmahl (eds), Die EU zwischen Niedergang und Neugründung (Nomos, 2020), p 181.

49 European Central Bank Press Release, Technical Features of Outright Monetary Transactions 6 September 2012, https://www.ecb.europa.eu/press/pr/date/2012/html/pr120906_1.en.html (1 April 2020).

50 Ibid.

51 As is well known, this program follows the famous 'Whatever it takes' announcement by ECB Director Mario Draghi of 26 July 2012. 
more or less outspoken rejection of these measures. ${ }^{52}$ The ECJ, however, in its Gauweiler judgment of 16 June $2015,{ }^{53}$ did not follow this path and rather explained what were the conditions an asset purchase program had to fulfil were it to be found to be in conformity with EU law-conditions that the OMT program evidently fulfilled. For the BVerfG, this judgment became a face-saving device in the sense that it took up these conditions in a more restrictive form and transformed it into a highly demanding parameter for future assessments of similar purchasing programs. ${ }^{54}$

It was therefore only a question of time, before this 'high-tension dialogue' should have been taken up again-now, however, with sharpened instruments the BVerfG deemed to have at its disposal. The immediate impulse came from the so-called 'Public Sector Purchase Programme'. This bond-buying program differed, however, under several aspects from the OMT programme: ${ }^{55}$

- The OMT programme was conceived as an immediate financial crisis response with regard to specific Euro countries in need of urgent help and prepared to accept a set of conditions.

- PSPP is not 'selective' like OMT measures were intended to be but rather a general monetary instrument intended to stabilise the Euro zone as a whole and to guarantee the monetary transmission mechanism. ${ }^{56}$ Consequently, it does not aim at the purchase of specially affected Euro countries like the OMT programme but bonds of all Euro countries shall be bought in proportion to the single Euro country's ECB share.

- The OMT programme did not know any limit in volume (according to Draghi's 'whatever it takes saying') but ironically there was no need to implement it because this bold announcement already sufficed to reassure the markets without the need to spend any euro. By contrast, the PSPP has actually been implemented in practice. ${ }^{57}$ As the ECB set out in its press release of 22 January 2015, these measures were aimed at fulfilling the ECB's price

52 See Häde, note 48 above, pp $182 \mathrm{ff}$.

53 C-62/14, ECLI:EU:C:2015:400, Judgment of 16 June 2015.

54 Häde, note 48 above, p 184.

55 See also A Lang, 'Ultra Vires Review of the ECB's Policy of Quantitative Easing: An Analysis of the German Constitutional Court's Preliminary Reference Order in the PSPP Case, Bundesverfassungsgericht, Order of July 18 2017, BvR 859/16 etc., PSPP' (2018) 55 CMLR 923, p 926.

56 The ECB defines the 'monetary transmission mechanism 'as the process through which monetary policy decisions affect the economy in general and the price level in particular'. See ECB, https://www. ecb.europa.eu/mopo/intro/transmission/html/index.en.html.

57 The specific basis for the PSPP program was created by the Decision (EU) 2015/774 of the European Central Bank of 4 March 2015 on a secondary markets public sector asset purchase programme (ECB/2015/10); OJ L 121, 14.5.2015, pp 20-24. The rate of monthly security purchases is set out in the PSPP judgment of 5 May 2020, para 5(ss): It started with $€ 60$ billion, was then raised to $€ 80$ billion and afterward reduced, first to $€ 60$ billion, then to $€ 20$ billion and eventually to $1 € 5$ billion. 
stability mandate. '[T]his programme will see the ECB add the purchase of sovereign bonds to its existing private sector asset purchase programmes in order to address the risks of a too prolonged period of low inflation' ${ }^{58}$

The ECB attempts to operationalise the goal of price stability ${ }^{59}$ with 'inflation rates of below, but close to, $2 \%$ over the medium term'. ${ }^{60}$

While price stability, as such, has traditionally been a central battle cry for the advocates of German monetary sovereignty, with regard to the PSPP programme, they surmised that in reality this instrument had totally different aims and effects: in their complaints before the BVerfG presented in 2015 and 2016, they accused this programme of violating the prohibition of monetary financing of national budgets according to Article 123 TFEU, of being primarily an economic policy instrument going beyond the competences of the EU in general and of the ECB in particular, and of being detrimental to specific German economic interests. In view of the far-reaching differences between the OMT and PSPP programmes, with the latter widely taking into account the criticism presented against the former, the BVerfG could have easily dismissed these claims. The German Constitutional Court, however, declared them as admissible and issued a preliminary reference order on 18 July 2017. In this order, the BVerfG changed tactics: it was no longer the admissibility of the securities purchasing programmes as such the Constitutional Court focused at but it were rather the modalities of their implementation as to which doubts were raised. ${ }^{61}$ What at first glance might appear to be a gesture of at least partial deference, at a closer examination revealed to be an approach of insidious characteristics: it is extremely difficult to determine whether, on the technical level, there are such specific modalities and of what kind they should be. Or to put it differently: by directing the discussion into such uncharted waters it became far easier for the BVerfG to impose criteria for bond-buying programmes the EU (or, in practice, the European Central Bank) was not able or not prepared to fulfil. By declaring them as non-derogable minimum standards and as core constitutional criteria, a fundamental conflict between the German constitutional order and the EU system could be provoked without there being any convincing solution at hand.

The preliminary questions presented by the BVerfG to the ECJ were mostly unproblematic as they have been answered, by and large, already by previous preliminary rulings, in particular by Pringle ${ }^{62}$ and Gauweiler. ${ }^{63}$ The most delicate questions concerned, however, the exact distinction between monetary and economic policy as well as the question whether and how a proportionality test should be

\footnotetext{
58 ECB Press Release, ECB Announces Expanded Asset Purchase Programme (22 January 2015), https://www.ecb.europa.eu/press/pr/date/2015/html/pr150122_1.en.html.

59 See Art 119, paras 2-3 TFEU, as well as Art 127 TFEU as to the primary objective of the European System of Central Banks.

60 ECB, Monetary Policy, https://www.ecb.europa.eu/mopo/html/index.en.html.

61 See Lang, note 55 above, pp $928 \mathrm{ff}$.

62 C-370/12, EU:C:2012:756.

63 C-62/14, EU:C:2015:400.
} 
taken recourse to assess whether monetary instruments having also effects in the field of economic policy can find application.

In Weiss, ${ }^{64}$ the ECJ has given, as far as possible, answers to these questions. As the BVerfG has stated afterwards in the PSPP judgment, these answers were insufficient and 'simply not comprehensible', and the Weiss judgment was therefore dismissed.

Maybe the ECJ should have taken heed of the advice by the Italian Government, which opined that the ECJ should declare the request for a preliminary ruling inadmissible as the referring court in any case would not accept the ruling as binding and consider itself ultimately responsible for deciding on the basis of the GG. ${ }^{65}$ In the end, this was exactly what happened.

\section{THE PSPP JUDGMENT OF 5 MAY $2020^{66}$}

\section{A. Conflicting Positions and Conflicting Readings of the Controversy}

By the PSPP judgment of 5 May 2020, the unthinkable became real: the breach between BVerfG and ECJ, throughout the whole Solange dispute only a theoretical option, a menace in order to steer ECJ jurisprudence and EU bodies' activities in a direction more adherent to German constitutional policy, had now become a fact both the European Union and its Member States have to deal with.

This judgment provoked an enormous stir all over Europe: in politics (both national and European ${ }^{67}$ ), in the judicial area ${ }^{68}$ and in the academic world. ${ }^{69}$

\footnotetext{
64 C-49317, EU:C:2018:1000.

65 Ibid, para 17(f).

66 BVerfG, Second Senate, 5 May 2020, 2 BvR 859/15.
}

67 In response to a Parliamentary question proposed by the German MEP Sven Giegold of 9 May 2020 the President of the EU Commission Ursula van der Leyen answered the same day by stating the EU Commission 'is taking this issue very seriously' and that 'further steps up an infringement procedure' will be examined. See https://sven-giegold.de/gute-nachricht-rechtsgemeinschaft. ). On 9 June 2021, the European Commission started the infringement procedure by sending a letter of formal notice to Germany.

68 It was surprising to see how in the aftermath of the PSPP judgment, judges sought the public limelight. If it was not out of remorse, this behaviour surely revealed that these judges felt the necessity to justify their action before the broader public. For judges this was a rather unusual gesture. See eg https:// www.sueddeutsche.de/politik/ezb-urteil-bundesverfassungsgericht-anleihenkaeufe-peter-michael-huber1.4905311?reduced=true; https://www.faz.net/aktuell/politik/inland/peter-huber-im-gespraech-dasezb-urteil-war-zwingend-16766682.html; https://www.tagesschau.de/inland/interview-vosskuhle-101. html; https://www.zeit.de/2020/21/andreas-vosskuhle-ezb-anleihenkaeufe-corona-krise.

${ }^{69}$ See for example, the many posts on the Verfassungsblog, https://verfassungsblog.de/tag/pspp (most of them very critical of the PSPP judgment by the BVerfG) and the contributions in EuZW 2020 No 12. See also, for example, Bernhard Wegener, 'Karlsruher Urteil - Das Urteil des Bundesverfassungsgerichts vom 5. Mai 2020 (2 BvR 859/15) in Sachen Staatsanleihekäufe der Europäischen Zentralbank' (2020) 4 Europarecht 347, who characterised the PSPP judgment as 'a disastrous miscarriage of justice' ('verhängnisvolles Fehlurteil'). As will be seen, many of the commentaries published in the immediate aftermath of the publication of the PSPP judgment were extremely critical towards the BVerfG. Here, it will be tried to find a more balanced vision. 
This judgment lends itself to two readings: a 'Unionist' one (contrary to its main finding) and a 'German constitutionalist' one (in favour of them, evidently in the minority). Both perspectives could be further differentiated but let us, in a first moment, juxtapose them neatly (and in most cases these positions were clearly defined).

On this basis, a consensus or a compromise between these two opposite camps can hardly be found.

The 'Unionists' contend two major violations:

- The bindingness of preliminary rulings by the ECJ is no longer accepted

- The autonomy of the ECB suffers a major inroad: the BVerfG takes the liberty of second-guessing the ECB's institutional decisions which, as a matter of rule, should fall into this institution's autonomous powers. ${ }^{70}$

The 'German constitutionalists' adopt a completely different perspective when they try to defend the BVerfG's right to 'autonomous assessment' of measures that in any way are either outside EU competences (and then we are confronted with an ultra vires situation) or raise an 'identity' issue, when they concern EU measures that touch upon the constitution's 'inviolable core content'.

Both positions leave many questions open. As will be shown below, it may not be possible to state what is the 'right' position, even though the 'German constitutionalist' is surely not tenable, at least not in its radical form, if present achievements of European integration are to be preserved. At the end, this confrontation mirrors a deeper cultural and political clash about the future of European integration. It is a conflict about pre-dominance resulting from 'constructive ambiguity ${ }^{71}$ nested into pivotal norms regulating EMU. And this 'constructive ambiguity' is, at the end, an expression of the conflicts mentioned before and still unresolved notwithstanding the introduction of the European Stability Mechanism, the adoption of the Fiscal Pact, and several salvage packages. It will be argued here that a definite solution of the conflict made apparent by the PSPP can be solved, if at all, only by a new compromise to be transformed into positive primary law, introducing new mechanisms of solidarity, ${ }^{72}$ and new perspectives for the further development of the European Union.

\footnotetext{
70 As Annamaria Viterbo has pointedly formulated: The BVerfG judgment [...] is putting sand in the wheels of the ECB'. See A Viterbo, 'The PSPP Judgment of the German Federal Constitutional Court: Throwing Sand in the Wheels of the European Central Bank' (2020) European Papers 1, p 14. See also P Bofinger, et al, 'Gefahr für die Unabhängigkeit der Notenbank' (Frankfurter Allgemeine Zeitung, 29 May 2020), https://www.faz.net/aktuell/wirtschaft/ezb-warum-die-unabhaengigkeit-der-notenbank-ingefahr-ist-16790569.html.

71 The notion of 'constructive ambiguity' as such is sometimes credited to Henry Kissinger: 'Constructive ambiguity' (Wikipedia, 18 January 2020), https://en.wikipedia.org/wiki/Constructive_ ambiguity; B Keller, 'Mitt and Bibi: Diplomacy as Demolition Derby' (The New York Times, 13 September 2012). In reality, however, this concept is much older as it refers to the concept of 'dilatorischer Formelkompromiss' coined by Carl Schmitt who was again influenced in this by Hans Morgenthau (many thanks to Karine Caunes for this hint)

72 On the solidarity issue, see P Hilpold, "Understanding Solidarity within EU Law: An Analysis of the "Islands of Solidarity" with Particular Regard to Monetary Union' (2015) 34 Yearbook of European Law 257.
} 


\section{B. The Reach of BVerfG Jurisdiction: Does It also Encompass EU Law?}

The PSPP judgment can be seen as the final act in a long controversy over enhanced solidarity measures in favour of some states of the Euro zone, which were severely hit by the economic and financial crisis. This assistance met with growing criticism within the German population amid a continuous flow of press reports-often referring to renowned German economic experts- which portrayed these aids as economically senseless and detrimental for Germany. ${ }^{73}$

What should actually be the object of BVerfG control, if anything, found diverging answers by the Court, and these answers give rise to doubts up to this day. ${ }^{74}$

\section{The Main Findings}

During the procedure in the PSPP case before the BVerfG, many confided that eventually the German Constitutional Court would continue its policy of a constructive dialogue with the ECJ. ${ }^{75}$ Although when the procedure was re-opened before the BVerfG after the ECJ had issued the Weiss judgment, observers noted a frozen climate and an attitude openly adversarial towards the ECJ. ${ }^{76}$

The main findings of the PSPP judgment were the following:

- The BVerfG found no definite evidence for prohibited monetary financing of Member States according to Article 123 TFEU. According to the BVerfG, as to this point, the ECJ's arguments 'raise considerable concerns' but nonetheless they 'can still be considered tenable from a methodological perspective'. ${ }^{77}$

- Radical criticism is voiced against the ECB for launching and continuing the PSPP programme ${ }^{78}$ while disrespecting the principle of proportionality. For

\footnotetext{
73 See https://www.bild.de/politik/fotos/griechenland-krise/fotos-presse-18998808.bild.html; https:// www.bild.de/politik/inland/griechenland-krise/bild-sagt-nein-teil-1-22845526.bild.html. Only much later, mass media reported that Germany was, contrary to the general belief, the greatest profiteer of these transfers: https://www.sueddeutsche.de/wirtschaft/griechenland-hilfe-deutschland-milliardengewinn-1.4025519; https://www.bild.de/geld/wirtschaft/griechenland-krise/deutschland-macht-2-9milliarden-gewinn-mit-griechenland-hilfe-56074404.bild.html.

74 For a good overview of these caselaw developments, see H Sauer, 'Der novellierte Kontrollzugriff des Bundesverfassungsgerichts auf das Unionsrecht' (2017) EuZW 186.

75 See, for example Lang, note 55 above, p 950; A Mooij, 'The Weiss Judgment: The Court's Further Clarification of the ECB's Legal Framework' (2019) 19 MJ 449: '[T]he Weiss case appears to be the last in Euro crisis case law [...]'. Ibid, p 450.

76 See Häde note 48 above, p 191; F Mayer, 'Die EZB vor Gericht - die nächste Runde' (2015) EuZW 121.

77 PSPP Judgment, para 116. By the way, this finding, although not stating any unlawfulness by the ECJ, is nonetheless highly problematic from the perspective of EU law. In fact, it evidences clearly that the German Constitutional Court sees itself as the ultimate arbiter also for the interpretation of EU, both in a substantial and in a methodological sense. Graciously, the BVerfG concedes-with heavy heartthat the ECJ's arguments are still tenable.

78 By Decisions (EU) 2015/5103, (EU 2015/2464, (EU) 2016/702, and (EU 2017/100.
} 
the BVerfG, this instrument, qualified as monetary tool, may in reality have disproportional effects in the field of economic policy.

- This criticism is as such problematic - one has to ask how the BVerfG dares to criticise the autonomous exercise of the ECB's functions. Next follows a contorted reasoning by the BVerfG about the nature and the consequences of the PSPP decisions taken by the BVerfG. At paragraph 117, they are definitely qualified as ultra vires, but at paragraph 116, the BVerfG states that it cannot yet be definitely determined whether the ECB decisions at issue satisfy the principle of proportionality'. 79

- The failure by the ECJ to control the activity by the ECB adequately, thus resulting in ultra vires acts, is qualified in sharp tones: 'simply not comprehensible', 80 'simply untenable', 81 'not comprehensible and thus objectively arbitrary', 82 and 'no longer tenable from a methodological point' ${ }^{83}$

- The Federal Government and the German Bundestag are accused of being in breach of the constitution for 'failing to take suitable steps challenging that the ECB [in launching and continuing the PSPP programme] neither assessed nor substantiated that the measures provided for in [the relevant] decisions satisfy the principle of proportionality'. ${ }^{84}$ As explained above, already in a procedural sense, such a finding is highly problematic as it is based on the assumption that the BVerfG may challenge acts of omission by political organs notwithstanding the broad discretion they may have in this area. Furthermore, to ground such a claim on a right to democracy, self-determination (Article 20(1) and (2) GG) and free elections (Art. 38 (1) GG) and to consolidate it in the 'eternal clause' according to Article 79 (3) is far-fetched to say the least.

- The BVerfG identified a constitutional obligation by the Federal Government and the Bundestag 'to take steps seeking to ensure that the ECB conducts a proportionality assessment in relation to the PSPP' ${ }^{85}$ Following a transitional period of no more than three months allowing for the necessary coordination with the European System of Central Banks ('ESCB'), the Bundesbank may no longer participate in the implementation and execution of the relevant ECB

\footnotetext{
79 It has been argued in literature that these contradictions are due to controversies internal to the $2^{\text {nd }}$ Senate with a judge Rapporteur (Peter Huber) strictly considering that there had been a breach of the principle of proportionality while other judges had less radical views. At the end, so was argued, these different approaches were not adequately reconciled. See B W Wegener, 'Karlsruher Unheil Das Urteil des Bundesverfassungsgerichts vom 5. Mai 2020 (2 BvR 859/15) in Sachen Staatsanleihekäufe der Europäischen Zentralbank' (2020) Europarecht 347, p 352.

80 PSPP Judgment, para 116.

81 Ibid, para 117.

82 Ibid, para 118.

83 Ibid, para 119.

84 Ibid, para 116.

85 Ibid, para 232.
} 
decisions, unless the ECB makes good for its previous (purported) deficits in reasoning. ${ }^{86}$ One is left to wonder how these steps the Federal Government and the Bundestag and BVerfG seem to be obliged to shall appear in practice, given the fact there is no official communication channel between these institutions. In practice, all these institutions could issue declarations as they deem fit and continue with the PSPP without these facts having any immediate effects. Only in a new procedure, in what would seem to be an infinite regress, the BVerfG could examine whether the measures taken were sufficient (or, perhaps, 'proportionate').

- While, in case of the ECB, figuratively we could speak of a 'release on parole' (even though the ECB might question jurisdiction as well as the meaning of the obligations imposed and how to fulfil them) the condemnation of the ECJ was without parole and associated with strong morale reproach: according to the BVerfG the Weiss judgment was-in the parts referring to the proportionality issue- 'simply not comprehensible' and therefore rendered ultra vires. ${ }^{87}$ The delimitation of competences was 'simply untenable', ${ }^{88}$ the interpretation of the Treaties 'simply not comprehensible and thus objectively arbitrary' ${ }^{89}$ By its inobservance of the principle of proportionality, according to the BVerfG, the Weiss judgment of 11 December 2018 'manifestly exceeds' the mandate conferred to the ECJ by Article 19(1), second sentence TEU 'resulting in a structurally significant shift in the order of competence to the detriment of the Member States. To this extent, the [Weiss Judgment] constitutes an ultra vires act and thus has no binding effect (in Germany)'. ${ }^{90}$ By this formula, the BVerfG activated the 'Honeywell clause', ${ }^{91}$ revealing at the same time all its weaknesses: what was thought to be a formula that would lead to the ascertainment of an ultra vires act only in extreme situations of a constitutional breach by EU institutions or by national organs implementing EU law, in reality translates into a blanket formula allowing the German Constitutional Court to identify such a breach in nearly any situation if this Court so wishes. This formula is of no real material substance. The 'structural significant shift in the order of competence to the detriment of the Member States' happens if the BVerfG says so. It is the BVerfG that can activate the rupture if it feels like it. ${ }^{92}$ And in order to exclude any doubts as to these asserted powers, the

86 Ibid, para 235.

87 Ibid, para 116.

88 Ibid, para 117.

89 Ibid, para 118.

90 Ibid, para 119.

91 Honeywell Order, BVerfG, 6 July 2010, 2 BvR 2661/06, ECLI:DE:BVerfG:2010: rs20100706.2bvr266106, BVerfGE 126,286.

92 This fact has at least indirectly been confirmed in an appallingly candid way by the Judge Rapporteur Peter Huber in an interview with the 'Süddeutsche Zeitung' of 13 May 2020, p 5 ('Spieler auf Augenhöhe'): 'Wenn wir freundlicher argumentiert hätten, hätten die Tatbestandsvoraussetzungen für einen Ultra-vires-Akt nicht vorgelegen'. ('If we had argued in more friendly way, the elements for a ultra vires act would not have been given'.). Thereby Judge Huber confirmed that for the BVerfG, the relative 
BVerfG also re-adapted the Honeywell formula: while the Honeywell formula is based on some sort of 'error tolerance', in the sense that some violations might be acceptable without generating a constitutional conflict, in the PSPP judgment, this accommodating element is no longer mentioned. ${ }^{93}$

\section{The Distinction between Monetary and Economic Policy}

At the core of the whole legal controversy that has led, according to the BVerfG, to a 'structurally significant shift in the order of competence' and to ultra vires acts by the European Union not applicable in Germany and with no binding effects in relation to German constitutional organs, administrative authorities, and courts, ${ }^{94}$ stands the question how to distinguish monetary and economic policy. While the TFEU might not be fully clear in this regard, much additional confusion has been created by the jurisprudence of the BVerfG over the last few years. It is this jurisprudence that attempts to come to grips with a complex economic issue by legalistic constructions widely apart from the economic reality.

As is well known, the structure of EMU widely reflects German preferences and experiences with stability policy based on a strong central bank giving priority to price stability and opposing state financing and shared financial liability. ${ }^{95}$ In imposing this orthodoxy, the German Government operated out from a penumbra between law and politics, where national pride over an apparent success story with a strong currency met with elements of the German constitution seemingly requiring the government to maintain this policy. ${ }^{96}$ Accordingly, monetary policy became in Article 119 TFEU an exclusive EU competence with the primary objective of price stability, topped off with the obligation to support the general economic policies in the Union. The problem is, and it is here where the misunderstandings with mostly German lawyers start, that monetary policy is part and parcel of economic policy. The idea to distinguish them neatly is unrealistic, and gives, if anything, proof of little economic knowledge. ${ }^{97}$ In a certain sense, this situation appears to be a caricature of an interdisciplinary discourse gone awry. The formula chosen in Article 119

\section{(F'note continued)}

statement by the Court has constitutive effects as to the constitutional rupture the Court wants to pursue. FC Mayer referred to this interview in the EUI-Webinar 'Legal, Economic and Political Implications of the GCC Ruling on ECB’ of 21 May 2020.

93 See also F Mayer, 'Der Ultra vires-Akt' (2020) 75 JuristenZeitung 725, p 731.

94 PSPP Judgment, para 234.

95 See K Dyson and K Featherstone, The Road to Maastricht: Negotiating Economic and Monetary Union (Oxford university Press, 1999), in particular the chapter on 'Negotiating EMU Around the German Model: Agenda-Setting Under the Kohl Chancellorship, 1982-1989', pp 256 ff.

96 Matthias Herdegen speaks in this context of 'Verfassungserwartungen' ('constitutional expectations') requiring the creation of a 'community of stability' ('Stabilitätsgemeinschaft'): see M Herdegen in T Maunz and G Dürig (eds) Grundgesetz. (Beck, 2018), Article 88 GG, para 34.

97 See also S Dullien, 'Argumentationsdefizit des BVerfG' (2017) 9 Wirtschaftsdienst, p 608: 'From the viewpoint of modern macro economics to distinguish between monetary policy and "economic management" is simply absurd' (translation by this author). 
TFEU is intended to allow the introduction of a common currency without harmonising national economic policy, a step too far in an EU that wants preserve core sovereign characteristics of Member States and, first of all, national budgetary responsibility.

This has as a consequence that there is no state financing and no common budgetary responsibility. As it seems, 'economic policy' means different things to different people in different situations. A good, legally and economically sound interpretation of Article 119 TFEU has been provided by Advocate General Cruz Villalón in the Gauweiler case $^{98}$ :

[In] order for a measure of the ECB actually to form part of monetary policy, it must specifically serve the primary objective of maintaining price stability and it must also take the form of one of the monetary policy instruments expressly provided for in the Treaties and not be contrary to the requirement for fiscal discipline and the principle that there is no shared financial liability. If there are isolated economic-policy aspects to the measure at issue, the latter will be compatible with the ECB's mandate only as long as it serves to 'support' economic policy measures and is subordinate to the ECB's overriding objective. ${ }^{99}$

Similarly, but perhaps even a little more generous to discretion of the ECB, Advocate General Wathelet states in the Weiss case the following: ${ }^{100}$

[W]here it has been found that the objectives of the programme at issue and the instruments chosen for its implementation fall within the area of monetary policy, it is necessary but sufficient for the judicial body to find that guarantees which are theoretically sufficient exist to prevent that programme for pursuing, in reality, an overriding economic policy objective or from undermining the objective of price stability. ${ }^{101}$

Contrary to the stance taken by the BVerfG, the Advocate General is of the opinion that 'indirect effects' of a monetary measures (on economic policy) have to be accepted even if they are foreseeable. ${ }^{102}$ The ECJ supported this position. ${ }^{103}$

Fully appropriately, the ECJ, referring to the ECB's explanations during the procedure, stated that instruments of monetary policy that aim at safeguarding and restoring an appropriate monetary policy transmission must necessarily have certain effects on the real economy: it is their very function! ${ }^{104}$ A successfully conducted

98 C-62/14, Opinion of 14 January 2015.

99 Ibid, para 132.

100 Case C-493/17, Opinion of 4 October 2018.

101 Ibid, para 115.

102 Ibid, paras $111 \mathrm{ff}$.

103 See C-493/17 (PSPP), Weiss et al., Judgment of 11 December 2018, ECLI:EU:C:2018:1000, paras $62 \mathrm{ff}$.

104 Ibid, para 65. Bond-buying programmes (asset purchasing) may be part of the 'unconventional instruments of monetary policy' but they are still part of monetary policy and are taken recourse to if the 'traditional instruments' (in particular the interest tool) are no longer effective because of the 
policy of this kind will also change the refinancing costs for states-another point of criticism by the BVerfG as to the PSPP programme. The PSPP programme has been qualified-like the OMT programme previously_as an instrument to 'unblock' interrupted monetary policy transmission channels to the real economy. ${ }^{105}$ This does not, however, transform this instrument into (prohibited) instruments of economic policy, even if this means easing refinancing conditions for states.

As economic literature has shown very clearly, monetary policy instruments designed to unblock interrupted monetary policy transmission channels regularly lower refinancing costs for governments. ${ }^{106}$ This additional growth stimulus is generally welcomed and intended, notwithstanding the fact that refinancing costs for governments no longer fully reflect previous risk calculations. Economists wonder which monetary policy would be allowed if such effects had to be excluded: 'Any easing of monetary policy facilitates further state indebtedness'. ${ }^{107}$

But what about the principle of proportionality on which the BVerfG has put so much emphasis? In fact, according to the BVerfG, disrespect for this principle is even the most serious fault both by the ECB and by the ECJ. The mistakes made in the attempt to neatly distinguish between monetary and economic policy can fully be gauged only if the related discussion about the purported disrespect for the principle of proportionality is taken into consideration.

\section{E. The Principle of Proportionality}

According to the BVerfG, 'the principle of proportionality requires that the programme's monetary policy objective and the economic policy effects be identified, weighed, and balanced against one another. Where a programme's monetary policy objective is pursued unconditionally and its economic policy effects are ignored, it manifestly disregards the principle of proportionality enshrined in Article 5(1), second sentence and Article 5(4) of the Treaty on European Union' ${ }^{108}$

For the BVerfG, disregard of the principle of proportionality may violate the principles of democracy and the sovereignty of the people and end up in a violation of the principle of conferral. According to the German Constitutional Court, this omission of 'weighing and balancing' is at the roots of the identified ultra vires acts. ${ }^{109}$

\footnotetext{
(F'note continued)

'liquidity trap' according to Keynes. See F Heide, 'Note to the Weiss judgment, ECJ 11 December 2018, C-493/17 (PSPP), ECLI:EU:C:2018:1000' (2019) 74 JuristenZeitung 305, p 306.

105 See AG Villalón in Case C-62/14, Gauweiler, paras 115 ff, referring to the ECB's statement in the respective procedure.

106 See recently the detailed analysis by R-M Marquardt, 'EZB-Verfassungsgerichtsurteil: filigrane Rechtsauslegung verus pragmatische Geldpolitik?' (2020) 6 Wirtschaftsdienst 432.

107 Ibid, p 438: 'Jede Form einer geldpolitischen Lockerung erleichtert die Verschuldung der Staaten'.

108 See $\mathrm{n} 6$ of the headnotes to the PSPP judgment.

109 See headnote 6(a) of the PSPP judgment.
} 
Much has been written about the 'proportionality' issue in the immediate aftermath of the publication of the PSPP judgment. ${ }^{110}$ The PSPP judgment presents itself, at first sight, as an erudite piece on the principle of proportionality, written, however, in a lecturing tone. ${ }^{111}$ Based, primarily, on a 'typically German' reading of this principle $^{112}$ and citing a long list of judgments hardly suitable to corroborate its position, ${ }^{113}$ the BVerfG tries to sell its viewpoint as the general European one. For the BVerfG, the principle of proportionality has become an instrument of weighing and balancing that would allow for the attribution of measures to specific competences with mathematical precision. According to the BVerfG, this balancing is totally missing, both at the level of the ECB (where the 'operative' decisions are taken) and the ECJ (where these decisions should have been controlled). ${ }^{114}$ And the outcome of the-allegedly superficial — assessment of these measures by those two institutions is qualified, respectively, as 'not comprehensible from a methodological perspective' (at the level of the ESCB) and 'meaningless' (at the level of the ECJ). ${ }^{115}$

Strong criticism was voiced against these findings. ${ }^{116}$ However, these critics partly exaggerated in the opposite direction, taking recourse to extreme formalism. Thus, it was said that the principle of proportionality as stated in Article 5 (1), second sentence and Article 5(4) TEU applies for the exercise of given competences and not for their delimitation. Furthermore, it was contended that the BVerfG does not apply this principle to the delimitation of competences between the State and the

110 See, eg, T Marzal, 'Is the BVerfG PSPP Decision "Simply Not Comprehensible"? - A Critique of the Judgment's Reasoning on Proportionality' (VerfBlog, 9 May 2020), https://verfassungsblog.de/isthe-bverfg-pspp-decision-simply-not-comprehensible; I Pernice, 'Machtspruch aus Karlruhe: "Nicht verhältnismäßig? - Nicht verbindlich? - Nicht zu fassen..."' (2020) 31 EuZW No 12, 508, pp 511; J Öberg, 'The German Federal Constitutional Court's PSPP Judgment: Proportionality Review Par Excellence' (European Law Blog, 2 June 2020), https://europeanlawblog.eu/2020/06/02/thegerman-federal-constitutional-courts-pspp-judgment-proportionality-review-par-excellence; J Nowag, 'The BVerfG's Proportionality Review in the PSPP Judgment and Its Link to Ultra Vires and Constitutional Core: Solange Babel's Tower Has Not Been Finalised' (15 June 15), https://ssrn.com/ abstract=3634218 or http://dx.doi.org/10.2139/ssrn.3634218.

111 See Mayer, note 30 above, who paraphrased the basic attitude by the BVerfG with the following saying (of course, not actually pronounced by the BVerfG judges this way): 'Let's for a while explain to the ECJ how this principle of proportionality actually works' (translation by this author).

112 See, eg, Nowag, note 110 above, p 9. It is true, when the BVerfG states at paragraph 112 of the PSPP judgment that 'the methodological standards recognised by the ECJ for the judicial development of the law are based on the (constitutional) legal traditions common to the Member States ... which are notably reflected in the case-law of the Member States' constitutional and apex court of the European Court of Human Rights'. But it is not true that the ECJ could or should have regard, in this context, primarily of the German apex courts.

113 See PSPP Judgment, para 125. For a critical stance as to the relevance of the cited judgments, see Pernice, note 110 above, p 512.

114 PSPP Judgment, paras 133, 138.

115 For an extensive examination of how the ECJ dealt with the proportionality principle, see M Dawson and A Bobic (2019) 56 CMLR 1005. Though being critical about the ECJ's examination, this study eventually finds inconsistencies on both sides.

116 See the literature cited in note 110 above. 
Federal Units in Germany. ${ }^{117}$ It would therefore be incoherent for the BVerfG to apply this principle in the relations between the EU and its Member States. These arguments are not convincing. From its very logical structure, the proportionality principle operates not only 'internally' as to the exercise of a specific competence norm but also 'externally', as to the delimitation of the competence's outer borders. At least in extreme cases, it is therefore conceivable that disproportionate measures are no longer covered, partially or entirely, by a specific competence norm they allegedly are based on. ${ }^{118}$

Neither is it convincing to state that the BVerfG was incoherent when it applied the competence order to the EU federal order while excluding it for the German (domestic) one. The two situations are hardly comparable. While within the European Union the distribution of competences between the Union and its Member States is in a continuous flux, with the ECJ acting as an arbiter with far-reaching powers, the situation within the Federal Republic of Germany is far more consolidated. While in the former case the principle of proportionality can provide useful guidance (in the use of EU competences), in the latter case to allow reference to proportionality considerations for the delimitation of competences could put into question a competence order that is broadly accepted and widely transparent.

In summary, it can therefore be said that it would be unfair to chide the BVerfG for having referred to the principle of proportionality for examining whether a violation of competence norms to the detriment of Member States had happened, even though the argumentation by this Court was in many senses not tenable and 'stridently German'. The real problem was rather that the BVerfG tried to use the principle of proportionality (previously introduced by the ECJ in the Gauweiler judgment as a legal problem-solving instrument) to find a dividing line between monetary policy and economic policy where no such dividing line exists. The BVerfG aimed at devising legal clothes for economic instruments it thought to be separate and autonomous but which in reality are closely interconnected. It pursued this strategy with the utmost determination, thereby, however, only additionally evidencing the faultiness of this approach. As the economic literature has very well analysed, a series of questions for the BVerfG - probably well known to readers of German print media for the broader public_relating to the economic effects of the ECB's bond-buying programmes has remained unanswered. The problem is: if not even economists can give a satisfying answer to these-inherently economic-questions, how should lawyers?

The BVerfG expected the ECB to give an answer (under the control of the ECJ) on the effects of the bond-buying programme, 'for example' on 'public debt, personal savings, pension and retirement schemes, real estate prices and the keeping afloat of economically unviable companies'. ${ }^{119}$ And this was not enough. The German Constitutional Court expected furthermore that-in an overall assessment and

\footnotetext{
117 See BVerfG 81, 310, p 338.

118 For similar considerations, see M Ludwigs, 'Die Konsequenzen des PSPP-Urteils für die Kompetenzordnung der EU' (2020) 4 EWS 186, pp 188 ff.

119 See PSPP Judgment, para 139.
} 
appraisal-these effects should be weighed 'against the monetary policy objective that the programme aims to achieve and is capable of achieving'. ${ }^{120}$

Thereby, however, the BVerfG was widely overestimating the material possibilities and potential of economic analysis. The BVerfG provided, as mentioned, only a few examples for effects that the ECB should have measured and juxtaposed to the official monetary effects. But what are the further effects of these measures and who should decide which ones are to be considered? Even assuming that such a selection can be made in an 'objective' way, how should these effects be weighed against each other? And complexities do not stop here as has been demonstrated in economic literature. ${ }^{121}$ For example, what is the net effect of a bond buying programme that creates jobs but raises real estate prices (with positive effects for homeowners and negative effects for buyers) and eases access to credit for governments at the price of influencing the risk assessment? ${ }^{122}$

One can see immediately that every choice in this field is the expression of certain values and needs. We can hardly assume that these values and goals are all the same all over the Euro zone. The ones mentioned by the BVerfG rather sound again 'typically German'. Should the ECB have carried through a weighing and balancing according to a German preference or what the BVerfG retains as such? It is obvious that this cannot be expected from the ECB.

In summary, the expectations the BVerfG seems to nurture in the proportionality principle are widely exaggerated if they are not a mere pretext to advance specific German interests (or interests considered to be as such). ${ }^{123}$

\section{THE BVERFG ORDER OF 29 APRIL 2021 - FRIENDS LIKE BEFORE?}

Following the judgment of 5 May 2020, two applications were lodged before the BVerfG for an order of execution according to $\S 35$ of the Federal Constitutional Court Act (Bundesverfassungsgerichtsgesetz ('BVerfGG')).

According to these applications, the BVerfG should have compelled the Federal Government and the Bundestag to several implementation measures resulting from the PSPP judgment. For example, access to non-public documents furnished by the ECB was sought for as a declaration that the Federal Government was obliged

\footnotetext{
120 Ibid.

121 See Marquardt, note 106 above, p 439. See also Pernice, note 110 above, p 515.

122 See Marquardt, note 106 above, $\mathrm{p} 439$. As Bofinger, et al, note 47 above, point out, the yardstick for measuring this 'net effect' is totally missing. See in this sense also M Nettesheim, 'Das PSPP-URteil des BVerfG - ein Agriff auf die EU?' (2020) NJW 1631, p 1634.

123 See also P Koutrakos, 'The German Federal Constitutional Court on Bond Buying by European Central Bank and EU Law Supremacy' (Monckton Chambers, 2020), https://www.monckton.com/ the-german-federal-constitutional-court-on-bond-buying-by-european-central-bank-and-eu-law-supremacy: 'Proportionality review is no science. It is a malleable instrument that may be used in different ways in different contexts'.
} 
to take action in order to ensure that the Bundesbank refrains from further participating in the execution of the PSPP.

The applications were dismissed both as inadmissible and unfounded. They were characterised as inadmissible because an 'order of execution must not amend, modify, add or expand the decision on the merits which it serves to enforce'. ${ }^{124}$ According to the BVerfG the applications were directed at a request for a constitutional review of the measures taken after the judgment of 5 May 2020 was rendered, including an assessment of new legal circumstances, ${ }^{125}$ a request that cannot be based on $\S 35$ BVerfGG.

More interesting for the underlying substantive controversy in the PSPP case was the fact that the BVerfG considered the applications to be unfounded. As opposed to the PSPP case, the BVerfG now concentrated exclusively on the behaviour of the Federal Government and the Bundestag. In this, these constitutional organs were attributed the utmost autonomy: '[T]hey have a broad margin of appreciation, assessment and manoeuvre; they must consider existing risks and take political responsibility for their decisions'. ${ }^{126}$ The BVerfG enlisted a considerable number of measures taken by these two organs in the follow-up to the PSPP that should demonstrate the assessment of the PSPP programme's proportionality. ${ }^{127}$ The BVerfG refrained from any substantive qualification of these measures stating that only complete inaction would empower the Court to intervene. ${ }^{128}$

No doubt, this stance constitutes a radical change in attitude compared to the one taken in PSPP where this Court had stated that ' $[\mathrm{w}]$ here fundamental interests of the Member States are affected, as is generally the case when interpreting the competences conferred upon the European Union as such and its democratically legitimated European integration agenda (Integrationsprogramm), judicial review may not simply accept positions asserted by the European Central Bank without closer scrutiny'. ${ }^{129}$

It can be argued that the PSPP judgment would look radically different had the Second Senate of the BVerfG adopted a similar view already in that proceeding. However, even if the BVerfG refrains from addressing the substantive conflicts envisaged in the PSPP judgment, this does not mean that they would now be resolved.

\section{CONCLUSIONS}

For a few weeks, until the annunciation of an infringement procedure against Germany by the European Commission, the order of 29 April 2021 has seemed to

\footnotetext{
124 See para 77 of the Order of 29 April 2021.

125 Ibid, para 83.

126 Ibid, para 90.

127 Ibid, paras $95 \mathrm{ff}$.

128 Ibid.
}

129 Rec No 3 of the Judgment of 5 May 2020. See also PSPP Judgment, para 116. See M Nettesheim, 'Darlegungsanforderungen der EZB, Integrationsverantwortung und der Beschluss des Bundesverfassungsgerichts' (VerfBlog, 29 April 2021), https://verfassungsblog.de/das-ende-einesepochalen-verfassungsstreits. 
be a magic wand making all of the ghosts of a severe constitutional crisis that manifested after the judgment of 5 May 2020 disappear. In reality, however, the underlying conflicts continued to linger. If we adopt a broader temporal perspective, the order of 29 April was probably nothing more than one of these well-known steps backward in the Solange process heading continuously again towards conflict. In view of the ever-growing controversies within the European Union as to nature, dimension, and direction of economic and monetary cooperation, as well as to the meaning of solidarity (see now the discussion about the Recovery Program in the Post-COVID process), it may only be a matter of time until national courts return to the substantive issues hinted at in the PSPP judgment. However, they have to be settled by different means, by different legal arguments.

As the dust settles and we look behind all the legalistic rhetoric, in many cases based on weak dogmatic foundations, we see that it is not the assessments by the ECB or by the ECJ that are 'untenable' but this is rather the case for the main assumptions by the BVerfG in the PSPP judgment. The BVerfG wanted to establish criteria for the use of economic instruments that go well beyond what economic theory can realistically deliver. ${ }^{130}$ This may in part result from insufficient knowledge of economic theory and from an over-estimation of the potential of economic theory. In the end, this situation evidences the limits of interdisciplinary dialogue. The prerequisites for such a discussion to be meaningfully carried out are often not available. ${ }^{131}$ At the same time, however, it would also be wrong to exaggerate with criticism against the PSPP judgment in the sense that national constitutional courts should not be allowed to question respect of competences by the EU organs and in particular by the ECJ. Of course, an integration-friendly approach will place some confidence in the correct exercise of the EU organs' competences but in a Union that is not fully integrated and where the States remain the 'masters of the treaties' fundamental competence conflicts and even ultra vires acts cannot be ruled out. How to tackle such conflicts legally is still one of the great unsolved problems of European integration, much the same as it is the case with the opposite situation

\footnotetext{
130 It may be interesting to note that the jurisprudence by the German Constitutional Court has created similar interpretative problems at another intersection between law and economics: in the field of tax law and more precisely with regard to the ability to pay principle. The BVerfG has elevated this constitutional principle to an over-arching guiding principle that should determine with nearly mathematical precision the interpretation and application of single tax norms. Unfortunately, fiscal theory from which the ability to pay principle is coming from does not attribute such powers to this principle and legal theory (and not even constitutional legal theory) cannot surrogate for these deficiencies. See for this discussion, P Hilpold, Italienisches Steuerrecht, $2^{\text {nd }}$ ed (Nomos, 2017), pp $54 \mathrm{ff}$. On the other hand, it has been argued that legal method is independent from economic theory. Even if the subdivision between economic and monetary policy according to the EU treaties should be flawed (from an economic point of view) this would not influence legal interpretation. See M Ludwigs, 'Zwölf Thesen zum PSPP-Urteil des BVerfG vom 5.5.2020' (2020) EuZW 530, p 531.

131 By the way, the same may happen (and often happens) also on the opposite side. For a lawyer it may be baffling to see what expectations non-lawyers have as to the standards of justice and 'rightness' in the field of norm interpretation and application.
} 
discussed here where Members States (or their organs like their constitutional courts) wrongfully accuse the EU of violating the competence order. ${ }^{132}$

In view of the order of 29 April 2021 (and before June 9, 2021), it could be argued that on the practical level nothing happened. For the future, the ECB is only asked to conduct a more transparent policy and to make evident that the monetary policy objectives pursued are not disproportionate to economic and fiscal policy effects resulting from the programme. ${ }^{133}$ Such a view ignored, however, that the BVerfG, by the PSPP judgment, has set the direction for the future relationship between national constitutional courts and the ECJ in a radical new way. Both the autonomy of the ECB and the acceptance of the ECJ preliminary rulings' definite character are under threat. Most probably this was not even the immediate aim pursued by the Second Senate of the BVerfG. Of immediate interest were rather the broader substantives controversies underlying the bond purchasing programme.

Independently form the legal outcome of the infringement procedure started by the European Commission on 9 June 2021, it has become clear that these controversies can only be solved politically as they are essentially of a politically nature and they concern fundamental values and the choice of the great directions European integration should take. As we have seen, the lengthy discussion about an alleged violation of the principle of proportionality hides the fact that German institutions are eager to make sure that the further development of EMU respects typical German goals or at least goals that are retained to be in the primary interest of Germany: EU monetary measures should not hurt material values and assets dear to the German people. The underlying economic reasoning might be wrong and incomplete but the fears are real and the intent by the BVerfG to protect purported interests of the German people genuine.

\footnotetext{
132 For the present problem, it has been proposed to ask the ECJ for a preliminary ruling. It seems doubtable whether such a proceeding would really be helpful. Not only would the ECJ be 'iudex in causa propria' but any finding that a violation of the competence order had actually occurred would only exacerbate the conflict, in particular with a Court like the BVerfG which states that its findings which the ECJ would put into question are based on immutable constitutional law (with reference to the 'eternity clause' in Article 79(3) GG). See more extensively P Hilpold, 'Ein EUVertragsverletzungsverfahren gegen Deutschland wegen des PSPP-Urteils? Eine Abwägung von Für und Wider' (2020) 4 EWS 181. In general, it is evident that there is no neutral arbiter for such conflicts and it has been proposed to create exactly such an institution. See J Weiler, 'The European Union Belongs to Its Citizens: Three Immodest Proposals' (1997) 22 European Law Review 150, proposing in this context the creation of a 'Constitutional Council for the Community'. See also more recently, D Sarmiento Ramirez-Escudero and J Weiler, 'The EU Judiciary After Weiss - Proposing a New Mixed Chamber of the Court of Justice' (VerfBlog, 2 June 2020), https://verfassungsblog.de/the-eujudiciary-after-weiss. It may be countered that such a Court (or 'Grand Chamber') might shed too much light on such conflicts and to institutionalise their resolution might raise their number. Furthermore, it is not sure whether the decisions of such Court would enjoy sufficient authority. Once such a radical conflicts becomes evident it is perhaps more appropriate to look for a political solution that would enjoy broader support.
}

133 See PSPP Judgment, para 235. 
It might be argued that all this rhetoric about the need to protect (German) people's sovereignty and core constitutional values as to the right to free election by the German people is backward-oriented and hardly reconcilable with the basic consensus about European integration. But behind this controversy looms an even greater conflict about the future of EMU not even marginally discussed in the broader public. The basic orientation of EMU is now the object of contention. Two fundamental models are discussed in this context: ${ }^{134}$ on the one hand, there are states (in particular Germany) and institutions (like the Deutsche Bundesbank) favouring the continuation of the present 'decentralised' model based on the 'no bailout clause' according to Article 125 TFEU, the prohibition of monetary financing according to Article 123 TFEU and debt regulation by risk-depending interest. On the other hand, a more centralised system is advocated by the European Commission. ${ }^{135}$ This latter model should be based on an 'insurance approach' and create buffers to counter future financial shocks and disruption. While not aiming at a 'debt union' or a 'mutualising of debts' such a 'centralised European Fiscal Union' would surely be associated with stronger solidarity elements than they exist as of yet and European institutions would have a far more powerful say in financial issues of union-wide relevance. ${ }^{136}$

In the PSPP judgment, the BVerfG has taken a firm stance to defend the decentralised model for Europe and 'popular sovereignty' for the 'German Volk', their personal savings, pension and retirement schemes, and accessible real estate prices-in contrast to the 'European Volksgeist' as identified by the ECJ. ${ }^{137}$ As shown, the judgment of 5 May 2020 is in many ways untenable, both from a legal viewpoint as from the economic viewpoint, a subject the judges of the Second Senate claim to master as well as legal theory. ${ }^{138}$ The idea, however, that Member States' Constitutional Courts should be allowed, at least in extreme cases of competence conflicts, to examine whether EU acts are of an ultra vires nature, holds some appeal in view of the fact that the principle of conferral applies. ${ }^{139}$

134 For a good overview on this discussion, see F Heinemann, 'Die Währungsunion benötigt eine Fiskalunion - aber welche? Eine Analyse der Euro-Reformblockade' (2020) 2 Integration 101.

135 For some analysts there is no alternative to the centralised model if the Euro shall be preserved. See Pernice, note 110 above, p 519.

136 For more details about these models, see Heinemann, note 134 above. The 'centralised model' is propagated in Jean-Claude Juncker (in collaboration with Donald Tusk, Jeroen Dijsselbloem, Mario Draghi, and Martin Schulz), The Five Presidents' Report: Completing Europe's Economic and Monetary Union, 22 June 2015, as well as in COM(2017) 291 final, Reflection Paper on the Deepening of the Economic and Monetary Union. For a stocktaking on the role of solidarity within EMU see P Hilpold, Die Europäische Wirtschafts- und Währungsunion - Ihr Umbau im Zeichen der Solidarität (Springer, 2021).

137 See H Schepel and E Blankenburg, 'Mobilizing the European Court of Justice' in G de Búrca and JHH Weiler (eds), The European Court of Justice (Oxford University Press, 2011), p 11.

138 It is true that the BVerfG has invited economic experts for advice. But it has also been argued that already the choice of these experts may have influenced the outcome of the advice. See Häde, note 48 above, p 188.

139 Case C-314/85, Foto Frost, EU:C:11987:452, 22 October 1987, para 15 does not preclude this if Constitutional Courts focus on the reach of national competences. For a different opinion see the 
Nor was it wrong for the BVerfG, as several commentators criticised, ${ }^{140}$ to refer to the principle of proportionality when looking for the limits of Union competences. On the other hand, this conflict has drastically revealed the many lacunae in the federal model of the Union, the imperfections of EMU, and the uncertainties of the integration model. This model seems to be far away from the often-cited 'Hamiltonian moment' ${ }^{141}$ and unsure what kind of solidarity perspective should be adopted. Beyond all legalistic swaggering on both sides, these are the real, political problems to solve. As has been well-portrayed in literature, ${ }^{142}$ legally this problem is probably not solvable: both the BVerfG and the ECJ claim 'to be right' and as 'border organs' ('Grenzorgane') operating at the threshold between law and politics, they both are advocating Kelsenian 'basic norms' ('Grundnormen') that are mutually not reconcilable. In the attempt to over-trump the other Grundnorm, both sides have made legal errors and if they are weighed and balanced, it is difficult to say who is right and who is wrong, if the decision is not be taken merely on the basis of sympathies. ${ }^{143}$

\section{(F'note continued)}

Editorial Comment in (2020) 57 CMLR 968 where this whole subject is seen as a matter of 'exclusive competence of the ECJ over matters of EU law'. See also S Glaser, 'Europastrafrecht ultra vires?' (2020) $4 Z W F$ 1, p 1; and F Schorkopf, 'Wer wandelt die Verfassung?' (2020) 75 JuristenZeitung 734, who speaks of an 'increasingly self-referential' European Union ( $\mathrm{p}$ 738). According to this viewpoint, changes of the European constitution, apparently so intensively needed, should be initiated by the responsible political organs and not by the judiciary. On the factual level, however, EU law was surely developed further by the judiciary (see for example the developments in the field of the Union citizenship) and these legal innovations were afterwards accepted by the political organs. See on these particularities of the development of the European legal order, J Weiler, 'The Transformation of Europe' (1991) 100 Yale Law Journal 2405. For a strict defence of the principle of conferral, see D Grimm, 'Jetzt war es so weit' (FAZ 18 May 2020): 'The primacy of EU law extends only so far as the Federal Republic of Germany has ceded competences to the European Union'. For a critical stance against the continuous extension of EU competences by the ECJ see also, W Kahl, 'Optimierungspotenzial im “Kooperationsverhältnis” zwischen EuGH und BVerfG' (2020) NVwZ 824. 140 See, for example, Friedemann Kainer, 'Aus der nationalen Brille: Das PSPP-Urteil des BVerfG' (2020) EuZW 533, p 534; Marzal, note 110 above; Wegener, note 69 above, with respect to the fact that such proportionality test is new and cannot lead, upon its introduction, to a qualification of an act as ultra vires ( $\mathrm{p}$ 350). For a stance generally critical against most of the commentaries published in the immediate aftermath of the PSPP's judgment publication (and it was surprising how many they were), Haltern, note 34 above, p 819, who stated the following: 'Many commentaries limited themselves to adopting the function Union perspective and to keep on at emphasising primacy [...]' (translation by this author).

141 See, for example, D Schwarzer, 'Pushing the EU to a Hamiltonian Moment', German Council on Foreign Relations No 10 (20 May 2020); E Nowotny, 'Euro-Bonds, Corona und "Kriegsfinanzierung", (ÖGfE Policy Brief, 2020) No 9, p 5.

142 See F Mayer, 'Ultra vires-Akt' (2020) 75 JuristenZeitung 725, p 733.

143 See also M Goldmann, 'Discretion, Not Rules: Postunitary, Constitutional Pluralism in the Economic and Monetary Union' in G Davies and M Aubely (eds), Research Handbook on Legal Pluralism and EU Law (Edward Elgar, 2018): 'claims of identity can lead to a stalemate' (p 353). 
It is irony of sorts that Judge Rapporteur Peter Huber, probably one of the main advocates of this rupture, in a subsequent interview with the journal Süddeutsche Zeitung has also shown the decisive way out of this quagmire by stating the following: 'To us judges first of all befits humility'. ${ }^{144}$ This statement can be interpreted as a wise discernment that such a conflict about values, the future of European integration and between the 'German' and the 'European Volksgeist' should not be solved by the judiciary but on the political level, not strictly unilateral but in a dialogue with all stakeholders. ${ }^{145}$ It is only a pity that Judge Huber continued immediately afterwards as follows: 'I wished that this would be the case on all sides: Humility in front of [European] cohesion and towards the legitimacy of the European legal order'. ${ }^{146}$ This does, alas, not sound as if the BVerfG should set the first step in order to re-establish the previous Solange relationship as a dialogue based on mutual trust and respect. The retreat by the BVerfG order of 29 April 2021 on procedural grounds was not enough to calm definitely the waves. For the European Commission this move was not sufficient. To the surprise of many, on June 9, 2021, it sent a letter of formal notice to Germany in which the Commission pointed out that the PSPP judgment constituted "a serious precedent, both for the future practice of the German Constitutional court itself, and for the supreme and constitutional courts and tribunals of other Member States". ${ }^{147}$ While it is not yet clear whether this controversy will really end up before the ECJ, it has become apparent that further clarifications can no longer be avoided. ${ }^{148}$

Whatever the outcome of the infringement procedure started in June 2021 may be, it can generally be said that the 'weighing and balancing' the BVerfG has missed in the Weiss ECJ preliminary ruling will have to take place on a far broader scale, both in the BVerfG's relations with the $\mathrm{ECJ}^{149}$ as in regard to the values and goals to be taken into consideration for the future orientation of the European Union. It

\footnotetext{
144 'Uns Richtern steht in erster Linie Demut an' (Süddeutsche Zeitung, 13 May 2020), p 5 (translation by this author).

145 As Judge Lübbe-Wolff has pointedly states in her famous dissenting opinion in the OMT case: 'The question is $[\ldots]$ whether the national perspective which is properly held up against the Union perspective in certain cases of conflict [...] is still the appropriate and the constitutional one where a decision may have legal and factual consequences of the magnitude and reach at issue here':ote 47 above, $\mathrm{p} 28$. 146 'Ich wünsche mir, dass das bei allen so wäre. Demut vor dem Zusammenhalt und vor der Legitimität der europäischen Rechtsordnung'. Ibid (translation by this author).

147 See European Commission, June infringements package: Key Decisions, https://ec.europa.eu/ commission/presscorner/detail/en/inf_21_2743.

148 This seems also to be imperative in view of possible "contagious effects" in the jurisprudence of other Member States as we witness presently in Poland, in particular with regard to the judgment of the Constitutional Tribunal of 7 October 2021 (Case K 3/21).

149 In this context reference can be made to the 'relational style' of adjudication, a model developed by Marta Cartabia, president of the Italian Corte Costituzionale, to describe this courts adjudicative practice with regard to questions of EU law. See M Cartabia, 'Of Bridges and Walls: "Italian Style" of Constitutional Adjudication' (2016) 8 Italian Journal of Public Law 37, p 42.
} 
will be unavoidable to find a more solid model for the Union's monetary and fiscal policy ${ }^{150}$ and —closely associated with this question-for exercising solidarity within a Union with widely divergent levels of wealth, economic power and resilience. $^{151}$

150 Notwithstanding, it might sound somewhat exaggerated there is much truth in what Florian Sander analysed in the following sense: To separate monetary policy from fiscal policy means creating barriers that in reality do not exist. To abandon the attempt to draw such a dividing line means that no limits are set to monetary policy when crises are to be countered also by fiscal instruments. See F Sander, '"Gestörte geldpolitische Transmission" - eine kompetenzrechtliche Sackgasse' (2018) 73 JuristenZeitung 525, p 534.

151 Already several years ago, even before the Lisbon Treaty came into force, Robert Howse and Kalypso Nicolaidis suggested that global governance should be based on a concept of 'divided sovereignty' and a democratic ethos of 'other-regarding' and 'minority regarding'. See R Howse and K Nicolaidis, 'Democracy without Sovereignty: The Global Vocation of Political Ethics' in T Broude and Y Shany (eds), The Shifting Allocation of Authority in International Law (Hart, 2008), p 191. They ask to take seriously the need to compensate all those who for one reason or another tend to remain losers in our globalising world'. In the PSPP judgment, the BVerfG tends to look rather the other way. 